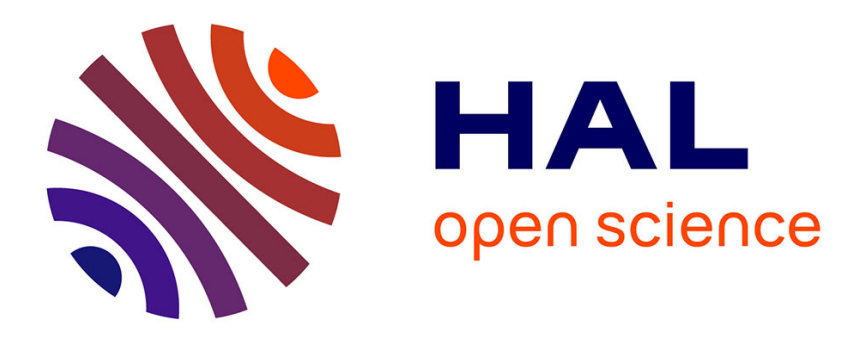

\title{
Time dependency of uterine effects of naringenin type phytoestrogens in vivo
}

Oliver Zierau, Georg Kretzschmar, Frank Möller, Carmen Weigt, Günter Vollmer

\section{- To cite this version:}

Oliver Zierau, Georg Kretzschmar, Frank Möller, Carmen Weigt, Günter Vollmer. Time dependency of uterine effects of naringenin type phytoestrogens in vivo. Molecular and Cellular Endocrinology, 2008, 294 (1-2), pp.92. 10.1016/j.mce.2008.08.008 . hal-00532064

\section{HAL Id: hal-00532064 https://hal.science/hal-00532064}

Submitted on 4 Nov 2010

HAL is a multi-disciplinary open access archive for the deposit and dissemination of scientific research documents, whether they are published or not. The documents may come from teaching and research institutions in France or abroad, or from public or private research centers.
L'archive ouverte pluridisciplinaire HAL, est destinée au dépôt et à la diffusion de documents scientifiques de niveau recherche, publiés ou non, émanant des établissements d'enseignement et de recherche français ou étrangers, des laboratoires publics ou privés. 


\section{Accepted Manuscript}

Title: Time dependency of uterine effects of naringenin type phytoestrogens in vivo

Authors: Oliver Zierau, Georg Kretzschmar, Frank Möller, Carmen Weigt, Günter Vollmer

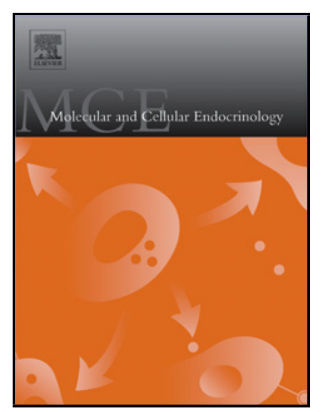

PII:

S0303-7207(08)00365-1

DOI: doi:10.1016/j.mce.2008.08.008

Reference: MCE 6951

To appear in: $\quad$ Molecular and Cellular Endocrinology

Received date: $\quad 26-2-2008$

Revised date: 29-7-2008

Accepted date: $\quad 11-8-2008$

Please cite this article as: Zierau, O., Kretzschmar, G., Möller, F., Weigt, C., Vollmer, G., Time dependency of uterine effects of naringenin type phytoestrogens in vivo, Molecular and Cellular Endocrinology (2007), doi:10.1016/j.mce.2008.08.008

This is a PDF file of an unedited manuscript that has been accepted for publication. As a service to our customers we are providing this early version of the manuscript. The manuscript will undergo copyediting, typesetting, and review of the resulting proof before it is published in its final form. Please note that during the production process errors may be discovered which could affect the content, and all legal disclaimers that apply to the journal pertain. 


\title{
Time dependency of uterine effects of naringenin type phytoestrogens in vivo
}

\author{
Oliver Zierau ${ }^{\mathrm{a}, \mathrm{b} *}$, Georg Kretzschmar ${ }^{\mathrm{a}, \mathrm{b}}$, Frank Möller $^{\mathrm{a}}$, Carmen Weigt ${ }^{\mathrm{a}}$ \\ and Günter Vollmer ${ }^{a}$
}

${ }^{a}$ Molecular Cell Physiology and Endocrinology, Institute for Zoology, Technische Universität Dresden, Germany

${ }^{b}$ These authors contributed equally to the results of this work

DISCLOSURE STATEMENT: The authors have nothing to disclose.

* Corresponding author:

Dr. Oliver Zierau,

Technische Universität Dresden,

Institut für Zoologie,

Zellescher Weg 20b, Raum 248,

01217 Dresden,

Germany

Tel.: +49-351-46 337841 Fax.: +49-351-46 331923

E-mail: Oliver.Zierau@tu-dresden.de

\section{Abstract}

Phytoestrogens exhibit significant estrogen agonistic/ antagonistic properties in animals and humans. Naturally occurring flavonoids with a naringenin backbone like 8-prenylnaringenin (8-PN) and 6-(1,1-dimethylallyl)naringenin (6-DMAN) are considered to be some of the most potent phytochemicals activating nuclear 
receptors. 8-PN is a more potent estrogenic substance while 6-DMAN appears to have a higher antiandrogenic potency, however these are less well characterized compared to other phytoestrogens such as genistein. The aim of this study was to assess the estrogenic properties of 8-PN and 6-DMAN in an ovariectomized in vivo rat model. 8-PN and 6-DMAN were applied at concentrations of $15 \mathrm{mg} / \mathrm{kg} \mathrm{bw}$. We assessed the uterotrophic response after $7 \mathrm{~h}, 24 \mathrm{~h}$ and $72 \mathrm{~h}$ of treatment. In contrast to 8-PN, 6-DMAN did not alter uterine wet weight or the level of expression of proliferation markers at any time point. In contrast to the uterotrophic response, 6DMAN stimulated uterine mRNA expression of estrogen responsive genes carrying an estrogen response element (ERE) in the ovariectomized rats, but to a lesser extent than E2 and 8-PN. In all treatment regimens the mRNA expression of estrogen receptors $\alpha$ and $\beta$ mRNA was measured. In summary, we assessed the time dependent uterine responses and estrogenic activities of 6-DMAN and 8-PN. In contrast to 8-PN which mimicked the E2 induced responses on uterine wet weight and gene expression, 6-DMAN has no uterotrophic effect and only regulated the mRNA expression of genes carrying an ERE. Therefore, 6-DMAN is an exciting candidate molecule for future investigations and potentially a natural occurring selective estrogen receptor modulator.

Keywords: Phytoestrogens, 6-(1,1-dimethylallyl)naringenin, 8-prenylnaringenin, Uterotrophy, Estrogen receptor, Estradiol

\section{Introduction}

The environmental estrogens from plants called phytoestrogens (PEs), have received extensive attention, for more then 60 years now, due to their widespread occurrence in a variety of products to which humans and animals are exposed to on a regular and sometimes continuous basis (Bennetts et al., 1946; Brown and Setchell, 2001; Singleton and Khan, 2003). Over the last few years, public as well as scientific interest in phytoestrogens, like genistein, has intensified due to their potential health benefits as. soy supplements and health foods containing concentrated amounts of phytoestrogens are been marketed extensively. However, PEs are a diverse group of plant-derived compounds that structurally or functionally mimic mammalian estrogens partial or in total and therefore may have a significant impact on human health (Cos et al., 2003; Ososki and Kennelly, 2003). However, 
regarding their use as pharmacological compounds, there is still an ongoing risk/benefit debate. Estrogenic effects are mostly mediated through the estrogen receptors $(E R)$. Since the discovery of a second $E R \beta$ (to differentiate from the original, subsequently named ER $\alpha$ (Kuiper et al., 1996; Byers et al., 1997), led to a re-evaluation of the physiology and toxicology of the estrogen signaling system. The biological significance of the two ER subtypes still remains unresolved, but may explain the selective and divers effects of estrogens occurring in different target tissues. Whereas ER $\alpha$ seems to be the prevalent ER subtype in the female reproductive tract, levels of both ERs are easily detectable in the gonads (Byers et al., 1997; Saunders et al., 1997). The preference of PEs for ER subtypes (Kuiper et al., 1998), leading to a potential organ selectivity of their actions and therefore being a potential naturally occurring selective estrogen receptor modulator (SERM), is of high pharmacological relevance. SERMs are distinguished from pure receptor agonists and antagonists. Their function is estrogen-like, but in contrast to the natural ligand estradiol they act in an organ selective and gene specific way (Vollmer and Zierau, 2004). The estrogenic effects of specific phytoestrogens have been characterized to different degrees (Whitten and Patisaul, 2001).

Phytoestrogens have been proposed as an alternative to classical hormone replacement therapy (HRT) treatment regimes. However, despite a vast number of studies published so far, evidence of the clinical effectiveness of PEs is very limited. A current metaanalysis proved that the beneficial effect of PEs on menopausal complaints are comparably small (Krebs et al., 2004). On the other hand, high dietary intake from soy PEs has been demonstrated to be connected to positive effects on (peri-)menopausal complaints (Nagata et al., 2001).

A group of recently described relatively potent phytoestrogens are of the naringenin type (Milligan et al., 1999; Milligan et al., 2002; Zierau et al., 2002). Especially 8prenylnaringenin (8-PN) from hops, Humulus lupulus (L.) and beer, initially described as 8-isopentenylnaringenin (Kitaoka et al., 1998) has been characterized as an extremely potent phytoestrogen (Kitaoka et al., 1998; Milligan et al., 1999; Schaefer et al., 2003). The estrogenic activity of 8-PN in vitro is the highest of all plant derived estrogens known so far (Matsumura et al., 2005). Another of these "novel phytoestrogens" is the flavonoid 6-(1,1-dimethylallyl)naringenin (6-DMAN) (Fig. 1) found so far only in the leaves of the African tree Monotes engleri (Gilg.) (Seo et al., 1997). We recently have described the estrogenic (Zierau et al., 2002) and 
antiandrogenic properties of 6-DMAN (Zierau et al., 2003). For both naringenins low toxicity and weak cytostatic properties were reported, making them good candidate molecules for further studies (Tokalov et al., 2004). 8-PN has been demonstrated to be a potent ER $\alpha$ selective phytoestrogen (Schaefer et al., 2003). For 6-DMAN the selectivity towards the two ER subtyps has not been investigated so far. The activity spectrum of a number of 8-alkylnaringenins spans from full E2-agonism to partial agonism to antagonism, including divers ER-subtype activity, only depending on the length and the bulkiness of the substituent (Roelens et al., 2006). In this study, to further elucidate the molecular basis of the difference of the estrogenic properties of 6-DMAN and 8-PN. To evaluate the specificity of these compounds for the ERa and $\beta$ we tested them using a reporter gene assay . in bone-derived U2OS cells as has been described before (Moller et al., 2007). In a second setting the estrogenic properties of 6-DMAN and 8-PN have been analyzed in vivo and compared to the estrogenic activity of E2. We performed a time resolved uterotrophic assay in ovariectomized female Wistar rats. The rats were treated with $15 \mathrm{mg} / \mathrm{kg} \mathrm{BW}$ of 8-PN or 6-DMAN per day, the positive control was E2 at $10 \mu \mathrm{g} / \mathrm{kg} \mathrm{BW}$ per day and the negative control was the carrier castor oil. Animals were treated time dependently for $7 \mathrm{~h}, 24 \mathrm{~h}$ and $72 \mathrm{~h}$ to assess the uterotrophic response profile of the substances. The genes for the for real-time-PCR quantification were chosen to reflect a range of target processes and regulatory mechanisms. Furthermore they allow for comparability with previous studies (Diel et al., 2004; Zierau et al., 2004; Kretzschmar et al., 2007).

\section{Materials and Methods}

\subsection{Substances}

17 $\beta$-estradiol (E2) was obtained from Sigma (Deissenhofen, Germany), 6-(1,1dimethylallyl)naringenin (6-DMAN) and 8-prenylnaringenin (8-PN) were synthesized from naringenin as described previously (Gester et al., 2001). The purity of the used compounds was assessed to be $>99 \%$ (gas chromatography and HPLC). 6-(1,1dimethylallyl)naringenin and 8-prenylnaringenin were used as racemic mixtures.

\subsection{Cell culture systems and plasmids}


U2OS cells were from ATCC/Promochem (Wesel, Germany). U2OS cells stably transfected with the ERa (U2OS-ERa cells), the ER $\beta$ expression plasmid and the (ERE)2-tk-Luc reporter plasmid were kindly provided by Dr. Luisella Toschi (Schering AG, Berlin).

\subsection{Reporter gene assays in U2OS cells}

U2OS cells were stably transfected with ERa (U2OS-ERa cells) and cultured routinely in DMEMF12 medium containing $10 \%$ fetal calf serum (FCS) and $0.5 \mathrm{mg} / \mathrm{ml}$ G418 (Calbiochem/VWR, Darmstadt, Germany). Experiments were performed in DMEM-F12 Medium containing 5\% dextran coated charcoal (DCC) stripped FCS and $0.5 \mathrm{mg} / \mathrm{ml} \mathrm{G418.} \mathrm{For} \mathrm{transfection,} \mathrm{U2OS-ERa} \mathrm{cells} \mathrm{were} \mathrm{transferred} \mathrm{to} \mathrm{a} 24$ well plate $(30,000$ cells/well) and transfected with $100 \mathrm{ng}$ of the (ERE)2-tk-Luc reporter plasmid using a liposome protocol (DOTAP; Roth, Karlsruhe, Germany) and a DOTAP:DNA ratio of 3:1. Luciferase activity was measured with a commercial kit (Promega, Mannheim, Germany) according to the manufacturer's instructions. Reporter gene assays in U2OS cells transiently transfected with ER (U2OS-ER $\beta$ cells), which do not express any ERs, were cultured routinely in DMEM-F12 Medium containing 10\% FCS. Experiments were performed in DMEM-F12 Medium containing $5 \%$ DCC. For transfection, U2OS cells were transferred to a 24 well plate $(45,000$ cells/well) and co-transfected with $100 \mathrm{ng}$ of the ER $\beta$ expression plasmid and $600 \mathrm{ng}$ (ERE)2-tk-Luc reporter plasmid using a liposome protocol (DOTAP; Roth, Karlsruhe, Germany) and a DOTAP:DNA ratio of 3:1. Luciferase activity was measured with a commercial kit (Promega, Mannheim, Germany) according to the manufacturer's instructions. 


\subsection{Treatment of cell cultures with the test substances}

All test substances were dissolved initially in DMSO and were used at a final DMSO concentration of $0.1 \%$. All assays were performed with different concentrations of the test substances specifically adapted to the respective assay in order to obtain doseresponse relationships (see legends to Figures).

\subsection{Animals}

Juvenile female Wistar rats (150 g) were obtained from Charles River (Charles River Laboratories, Sulzfeld, Germany) and were maintained under controlled conditions of temperature $\left(20^{\circ} \mathrm{C} \pm 1\right)$, relative humidity $(50-80 \%)$ and illumination $(12$ $\mathrm{h}$ light, $12 \mathrm{~h}$ dark). All rats had free access to standard rat diet (SSniff R10-Diet, SSniff $\mathrm{GmbH}$, Soest, Germany) and water. All animal handling and experimental conditions were in accordance with the Institutional Animal Care and Use Committee guidelines, regulated by the German federal law for animal welfare.

\subsection{Uterotrophic assay}

Animals were ovariectomized (ovx). After 14 days of endogenous hormonal decline the animals were treated for $7 \mathrm{~h}, 24 \mathrm{~h}$ and $72 \mathrm{~h}$ s.c. with the respective compounds. Negative control was the carrier castor oil. The animals were randomly selected for treatment and vehicle groups $(n=6)$. E2, 8-PN and 6-DMAN were administered s.c. with doses of $10 \mu \mathrm{g} / \mathrm{kg} / \mathrm{d}$ E2 and $15 \mathrm{mg} / \mathrm{kg} / \mathrm{d}$ for the PEs dissolved in carrier castor oil. These values correspond to the most potent doses of 6-DMAN and 8-PN tested in previous in vivo experiments (Diel et al., 2004; Zierau et al., 2004). The treatment of the animals was carried out two hours after the start of the light period of the day and subsequently the animals were sacrificed by $\mathrm{CO}_{2}$ inhalation after light anaesthesia with $\mathrm{O}_{2} / \mathrm{CO}_{2}$ inhalation after $7 \mathrm{~h}, 24 \mathrm{~h}$ and $72 \mathrm{~h}$ of treatment respectively. The uterus was excised, trimmed free of fat and cut just above its junction with the cervix and wet weight was determined. Thereafter the uteri were snap frozen in liquid nitrogen for RNA preparation. 


\subsection{RNA-preparation, reverse transcription and Real-time PCR}

The total cytoplasmic RNA was extracted from the rat uteri by the standard TRIzoI $\circledast$ method (Life Technologies). DNA residues were enzymaticly eliminated by digestion (Deoxyribonuclease I, Ambion) and removal was checked by PCR. SUPERSCRIPTTM II Reverse Transcriptase (Life Technologies) and Oligo (dT) 1218 were used for the first-strand cDNA synthesis

\section{8. $m R N A$ quantification using quantitative real time $P C R$}

Quantitative real-time PCR was carried out by Platinum® Taq DNA polymerase (Life Technologies) using the iCycler Thermal Cycler with iQ real-time Detection System. The reactions were run three times in triplicates. After vortexing 50 $\mu \mathrm{l}$ aliquots of the mix was pipetted in each well of the 96 well thin-wall PCR plate (Bio-Rad). PCR reactions consisted of a first denaturing cycle at $95^{\circ} \mathrm{C} 3 \mathrm{~min}$, followed by 50 cycles of $10 \mathrm{sec}$ at $95^{\circ} \mathrm{C}, 15 \mathrm{sec}$ at $60^{\circ} \mathrm{C}$ and $30 \mathrm{sec}$ at $72^{\circ} \mathrm{C}$. Fluorescence was quantified at the end of the $60^{\circ} \mathrm{C}$ annealing step and product identity was confirmed by a melting curve analysis $\left(60^{\circ} \mathrm{C}-95^{\circ} \mathrm{C}\right)$. Primer sequences and amplicon sizes are summarized in table 1.

The relative mRNA amounts of target genes ER $\alpha$ and $\beta$, complement C3, progesterone receptor $(\mathrm{PR})$, proliferation-related Ki-67 antigen, proliferating cell nuclear antigen (PCNA), cyclooxygenase 2 and vascular endothelial growth factor receptor 2 were calculated after normalization to an endogenous reference gene (Cytochrome C Oxidase subunit 1). Results were expressed as relative amounts of mRNA compared to the vehicle control animals using the $2^{-\triangle \Delta C T}$ formula (Winer et al., 1999).

\subsection{Western blot analysis of uterine protein expression}

Uteri were dissected from the animals and immediately stored in liquid nitrogen. Pooled frozen tissues was pulverized in liquid nitrogen and homogenized in a mixture (1: 1) of preparation buffer (240mM saccharose; $20 \mathrm{mM}$ PIPES; $10 \mathrm{mM}$ EDTA; $50 \mathrm{mM}$ NaH2PO4; $1 \mathrm{mM}$ PMSF in 2-propanol; $\mathrm{pH} 7,4)$ and freezing buffer $(400 \mathrm{mM}$ saccharose; 5mM PIPES; 5mM Tris; 10mM EDTA; 50mM NaH2PO4; pH 7,2). 
Protein concentrations were determined using bicinchoninic acid (VWR, Darmstadt, Germany). Equal amounts of protein samples $(30 \mu \mathrm{g})$ were loaded onto a 8,5\% SDSpolyacrylamide gel, electrophoresed and transferred to 0,45 $\mu \mathrm{m}$ PVDF membranes (Millipore, Massachusetts; USA). The PVDF membranes were blocked with $5 \%$ skim milk powder and incubated with specific antibodies for PCNA (1: 1.000, Dako Cytomation, Glostrup, Denmark) and Actin (1: 4.000; Sigma, Saint Louis; Missouri, USA) at room temperature for $1 \mathrm{~h}$, followed by incubations with Goat-Anti-Mouse horseradish-peroxidase (HRPO)-conjugated secondary antibody (1:10.000, Dianova, Hamburg, Germany) and Goat-Anti-Rabbit HRPO conjugated secondary antibody (1 : 30.000, Dianova, Hamburg, Germany), respectively, at room temperature for $1 \mathrm{~h}$. The Western blots were developed with a chemiluminescence ECL Plus western blotting detection system (GE Healthcare, Buckinghamshire, UK) and exposed to Amersham Hyperfilm ECL (GE Healthcare, Buckinghamshire, UK) at room temperature. The protein bands were quantified by densitometry using the LabWorks 4.6 software (UVP Ltd, Cambridge, UK). To account for inhomogeneous protein loading of the slots the ratio of the reference protein (Actin) to the target protein (PCNA) was calculated.

\subsection{Statistical analysis}

Statistical analysis of the data in this work was performed using two way analysis of variance followed by pair wise comparison of selected means using the Student's t-test. The criterion for significance was set ${ }^{*} p<0.05,{ }^{* *} p<0.01,{ }^{* * *} p<$ 0.001 as compared to the negative control.

\section{Results}

\subsection{Effect on $E R \alpha$ and $E R \beta$ activation}

The effect on ERa dependent activity was tested in stably transfected U2OS-ERa cells. For the ER $\beta$ dependent activity U2OS cells transiently transfected with ER $\beta$ (U2OS-ER $\beta$ cells) were used. While for 8-PN even at the lowest tested concentration a statistically significant induction luciferase reporter gene activity was detectable in 
U2OSERa, 6-DMAN showed this activity only starting at a concentration of $100 \mathrm{nM}$ (Fig. 2A and 2C)

After stimulation of the U2OS-ERß cells with 6-DMAN and 8-PN a statistically significant ERß-mediated induction of reporter gene activity was detected (Fig. 2B and 2D). The maximal activation for both substances was already present at concentrations of $10 \mathrm{nM}$ and was not much enhanced by further increasing the concentration.

\subsection{Uterus wet weight}

The uterotrophic response in ovariectomized Wistar rats was tested time dependent manner after $7 \mathrm{~h}, 24 \mathrm{~h}$ and $72 \mathrm{~h}$ of treatment. 8-PN and 6-DMAN were applied at concentrations of $15 \mathrm{mg} / \mathrm{kg} \mathrm{BW}$ per day (Fig. 3). Positive control was E2 at $10 \mu \mathrm{g} / \mathrm{kg}$ BW per day and as negative and the carrier control castor oil was used. Control animals had an average uterus wet weight of $0.185 \mathrm{~g} \pm 0,012 \mathrm{~g}$ after vehicle treatment at any time point. E2 treatment over $7 \mathrm{~h}$ and $24 \mathrm{~h}$ caused a significant increase in uterus wet weight between 1.7 to 1.9 fold, while uterus wet weight after $72 \mathrm{~h}$ increased even further to 3.7 fold. 8-PN like E2 caused a significant increase in uterus wet weight between 1.6 to 1.8 fold after $7 \mathrm{~h}$ up to 2.7 fold after $72 \mathrm{~h}$ treatment compared to the carrier control. In contrast to 8-PN, 6-DMAN did not show any significant effect on uterus wet weight at any time point.

\subsection{Gene and protein expression in the uterus}

The mRNA expression of ER $\alpha$ and $\beta$ have been detected in the rat uterus under all treatment conditions. Following $72 \mathrm{~h}$ of treatment with $\mathrm{E} 2$, in addition to the two naringenins, the uterine $E R \alpha$ mRNA showed a four fold down-regulation compared to in the carrier control animals (Fig. 4A). The same result was consistent for levels of ER $\beta$. The strongest response in the uterus was observed after $7 \mathrm{~h}$ to $24 \mathrm{~h}$ treatment for all test substances, while after three days of treatment the expression of ER $\beta$ mRNA recovered to higher levels which were still below baseline expression (Fig. 4B).

The regulation of mRNA expression of other estrogen sensitive genes in the uterus by E2 followed the expected response pattern. The complement $\mathrm{C} 3$ and the PR 
mRNA levels followed a time dependent pattern of expression (Fig. 5A and 5B). While complement C3 reached the highest expression levels already after $24 \mathrm{~h}$ of E2, 8-PN and 6-DMAN treatment, only for E2 treatment a significant increase persisted for $72 \mathrm{~h}$. Complement C3 expression follows a similar pattern of regulation in all treatment groups, while the PR mRNA expression pattern is substance dependent. $\mathrm{PR}$ expression is already up regulated following 7h of either E2 or 8-PN treatment. 6DMAN treatment leads to a delayed upregulation of gene expression following $72 \mathrm{~h}$ of treatment, while PR expression was already back to baseline levels after equally long E2 treatment.

mRNA expression of cyclooxygenase 2 (COX2) was transiently up-regulated after $7 \mathrm{~h}$, dropped to control levels at $24 \mathrm{~h}$ and appeared down regulated after $72 \mathrm{~h}$ of either $\mathrm{E} 2$ or 8-PN treatment, while 6-DMAN showed no effect on the expression level of COX2 at any of these time points (Fig. 6A). Clusterin gene expression was also significantly down regulated following administration of E2 at either the $24 \mathrm{~h}$ or $72 \mathrm{~h}$ time point, while 8-PN treatment only led to a significant down regulation of clusterin mRNA expression at the $24 \mathrm{~h}$ time point. 6-DMAN had no effect at any time point (Fig. 6B). The mRNA expression of the vascular endothelial growth factor (VEGF) and its receptor 2 (VEGFR2) was transiently upregualted in response to E2 and 8-PN following $7 \mathrm{~h}$ of treatment. 6-DMAN treatment had no significant impact on the expression of VEGFR2 and VEGF mRNA (Fig. 7A and 7B). The mRNA expression of proliferation markers PCNA and KI67 was transiently up-regulated by E2 as well as by 8-PN in a clear time dependent manner while 6-DMAN treatment at none of the time points showed an impact on the regulation of proliferation associated gene expression (Fig. 8A and $\mathbf{8 B}$ ). To validate the findings on mRNA expression of proliferation markers and uterotrophy data we additionally investigated the PCNA protein levels in all treatment groups. We see significantly higher PCNA protein levels following E2 treatment at the $24 \mathrm{~h}$ and $72 \mathrm{~h}$ time point. While 8-PN in tendency mimics E2 with regard to it's effect on the PCNA protein expression pattern, 6-DMAN treatment had no effect on PCNA levels at any of the time points, according to the densitometric analysis(Fig. 8C).

\section{Discussion}


It is well known that proliferation of endometrial cells is under the control of estrogens and that the risk of endometrial carcinoma increases with estrogen replacement therapy, (Ito, 2007). To study the influence of phytoestrogens in the absence of endogenous estrogen stimuli, we used ovariectomized female rats. Although widely used, the efficacy and safety of PEs as pharmacological compounds is still controversial. The preference of phytoestrogens for ER subtypes may result in a potential organ selectivity of their actions and is therefore of high pharmacological relevance. We therefore evaluated the receptor selectivity of 8-PN and 6-DMAN on the level of transactivation in bone-derived U2OS cells.

While 8-PN had a similar transactivation efficiency through both receptors 6-DMAN showed activity via the ER $\beta$ at 10 fold lower concentrations than via the ERa. This demonstrates a modest ER $\beta$ selectivity of 6-DMAN which has been observed for some other phytoestrogens as well (Kuiper et al., 1998).

A further aim of this study was to better characterize the estrogen-like substances naringenin-type phytoestrogens 8-PN and 6-DMAN in vivo.

We applied the three day uterotrophic assay in ovariectomized rats which can answer two fundamental questions related to the properties of candidate phytoestrogens: 1) Proof of principle of the in vivo estrogenicity, 2) assessment of potential uterotrophic effects and impact on uterine proliferation. The latter is related to safety issues because exclosure of uterine stimulation would suggest safety towards unwanted intermediate uterine bleeding or hyper proliferation of the uterus in a menopausal setting.

We analyzed the time course of the uterotrophic response in ovariectomized Wistar rats at $7 \mathrm{~h}, 24 \mathrm{~h}$ and $72 \mathrm{~h}$ time points respectively. E2 and 8-PN but not 6-DMAN significantly stimulated the uterine wet weight and this uterotrophic response for E2 and 8-PN followed as expected a clear time course. The lack of uterine stimulation of 6-DMAN as seen in the absence of uterotrophy was reflected in the deficiency of stimulating the mRNA expression of proliferation markers at any investigated time point. Conversely, E2 and 8-PN as expected from the observed uterotrophic response showed an upregulation of mRNA expression of the proliferation markers PCNA and KI67. These findings were confirmed by the PCNA protein data demonstrating that the observed changes in PCNA mRNA expression subsequently lead to altered protein levels in the E2 and 8-PN treated rats. In contrast to the 
uterotrophic response, 6-DMAN stimulated increased uterine mRNA expression of some estrogen responsive genes in the ovariectomized rats, but not as pronounced as seen with E2 and 8-PN.

In all treatment regimens, the expression of ER $\alpha$ and $\beta$ mRNA, essential for the mediation of estrogenic effects, could be demonstrated. While application of E2 and 8-PN caused a similar response pattern on the expression of all E2-regulated genes, confirming the mostly E2-agonistic nature of 8-PN, 6-DMAN treatment lead to a more complex pattern of gene regulation. With genes containing EREs or ERE half sites a 6-DMAN dependent regulation of expression could be shown. However the PR mRNA expression pattern apparently shows a delayed onset of upregulation following 6-DMAN treatment compared to E2 and 8PN treatment. On the other hand 6-DMAN had no observable effect on E2 regulated genes that do not possess EREs as regulatory elements.

The standard path of estrogen action is via ER dimerisation and binding to EREs in the promoter regions of target genes and leading to transcription. But additional pathways for estrogen action have been are suggested (Coleman and Smith, 2001) including ER modulating gene expression via protein-protein binding with c-Fos/c-Jun B (AP-1), Sp1 or through NF-kB (Ray et al., 1994; Kushner et al., 2000; Safe, 2001). These alternative response mechanisms have been referred as non classical pathways. To investigate these non classical pathways a non classical ER knock-in (NERKI) mouse was established on the background of an ER $\alpha$ knockout mouse supplemented with a zinc finger deficient ER $\alpha$ knock-in. In these mice, the ERE dependent pathway of estrogen action is compromised while tethering mechanisms by protein/protein interactions are retained (Jakacka et al., 2002). These NERKI mice have enlarged uteri with cystic hyperplasia (Jakacka et al., 2002) suggesting that the uterine weight is not regulated via ERE pathway. In addition, a more recent study has shown that uterine proliferation appears to be mediated by tethering mechanisms (O'brien et al. 2006). Apparently estrogenic effects of 6-DMAN are mediated by binding to EREs in the promoter regions of target genes and not by the described non classical pathways, which could explain the lack of an uterotrophic effect.

The 8-alkylnaringenins investigated by Roelens et al. (Roelens et al., 2006) show an activity spectrum spanning from full E2-agonism to partial agonism to antagonism, including differential subtype activity, only depending on the length and the bulkiness of the substituent. 6-DMAN, although possessing a different substituent, fits nicely 
within this range. Some authors suggest that 8-PN may have beneficial effects in postmenopausal women and may become an alternative to classical HRT treatment regimes (Rad et al., 2006). Our data indicate that 6-DMAN with its lack of uterine stimulation might match the criteria for HRT much better than the pure E2 agonist 8$\mathrm{PN}$, because it lacks the proliferational effect on the endometrial cells which may increase the risk of formation of endometrial carcinoma.

In conclusion, we have identified several important differences between the two examined naringenin compounds in a time dependent protocol in vivo. 8-PN acts as a pure E2 agonist in the uterus, based on its uterotrophic effect but also from the very similar pattern of gene expression following time dependent treatment. However, 6DMAN seems to primarily effect the expression of ERE dependent genes. Interestingly, in contrast to E2 treatment, no uterine wet weight gain was detected following 6-DMAN further highlighting the potential safety of 6-DMAN with respect to uterine stimulation and cancer development. The results from the bone-derived U2OS cells demonstrate that small structural differences of PEs lead to explicit differences in the receptor preference. The preference of 6-DMAN towards transactivation via the ER $\beta$ might add to the explanation of the observed differences in the regulation of gene expression in vivo and are one of the desired characteristics for a medication of menopausal complaints .

These findings highlight the significance of a systematic approach to investigate the differences in estrogenic effects of structurally related PEs and provide valuable information for future drug or tool compound discovery. They also indicate that 6DMAN acts as a naturally occurring SERM since it differentially regulates the expression of only a subset of estrogen responsive target genes in the rat uterus. 6DMAN might constitute an attractive candidate molecule for future investigations into its usefulness in HRT.

\section{Acknowledgments}

We are grateful to Dr. Jacintha O'Sullivan from the University College Dublin and St Vincent's University Hospital, Ireland for critical reading and editing of the manuscript. This paper was supported by the Deutsche Forschungsgemeinschaft Vo410/6-3 to Günter Vollmer. 
Table 1: Primers used for real-time-PCR quantification

Fig. 1: Chemical structures of (a.) 8-prenylnaringenin and (b.) 6-(1,1dimethylallyl)naringenin.

Fig. 2: Effects of 6-(1,1-dimethylallyl)naringenin and 8-prenylnaringenin on the activation of ERa and ERß in U2OS cells. (A) The effect of 6-(1,1-dimethylallyl) naringenin (6-DMAN) and (C) 8-prenylnaringenin (8-PN) on ERa activity in the stably transfected U2OS-ERa cells was investigated by measuring reporter gene-coupled luciferase activity. The relative luciferase units (RLU) were measured in the presence of DMSO ( $1 / 4100 \%)$, E2 (10-8 M) and 6-DMAN. " po0.05, ${ }^{* *}$ po0 $0.01,{ }^{* * *}$ po0.001. (B) and (D) ER $\beta$ dependent activation of reporter gene activity was investigated by transient cotransfection of U2OS osteosarcoma cells with an ER $\beta$ expression plasmid and (ERE)2-tk-luc reporter construct (for details see Material and methods). $\mathrm{ERr} 731 \mathrm{~s}$ activated the ERß-coupled reporter gene activity in a statistically significant manner, reaching an activity level similar to that exerted by $10^{-8} \mathrm{M}$ E2. Significance against DMSO control ( $1 / 4100 \%):{ }^{*}$ po0.05, ${ }^{* *}$ po $0.01,{ }^{* * *}$ po 0.001.

Fig. 3: Uterine wet weight following treatment of ovariectomized animals:

Uteri of untreated ovariectomized control animals (Co), ovariectomized animals treated with $10 \mu \mathrm{g} / \mathrm{kg} \mathrm{BW/} \mathrm{d} \mathrm{estradiol} \mathrm{(E2)} \mathrm{and} \mathrm{ovariectomized} \mathrm{animals} \mathrm{treated} \mathrm{with}$ 6-(1,1-dimethylallyl)naringenin (6-DMAN) and 8-prenylnaringenin (8-PN) at a concentration of $15 \mathrm{mg} / \mathrm{kg} / \mathrm{d}$ BW. Asterisks indicate values significantly different from the respective controls. ${ }^{*} p<0.05,{ }^{* *} p<0.01,{ }^{* * *} p<0.001$.

Fig. 4: Real-time RT-PCR analysis of uterine gene expression:

Expression of estrogen receptors (ER) $\alpha$ and $\beta$ mRNA was analyzed by quantitative real-time RT-PCR analysis. Data of uterine gene expression of untreated ovariectomized control animals (Co), ovariectomized animals treated with $10 \mu \mathrm{g} / \mathrm{kg}$ BW/ $d$ estradiol (E2) and ovariectomized animals treated with 6-(1,1- 
dimethylallyl)naringenin (6-DMAN) and 8-prenyInaringenin (8-PN) at a concentration of $15 \mathrm{mg} / \mathrm{kg} / \mathrm{d}$ BW. Significancies are indicated as described in Fig.3.

Fig.5: Real-time RT-PCR analysis of uterine gene expression:

Expression of Complement $\mathrm{C} 3$ and the progesterone receptor (PR) mRNA was analyzed by quantitative real-time RT-PCR analysis. Data of uterine gene expression of untreated ovariectomized control (Co), ovariectomized animals treated with 10 $\mu \mathrm{g} / \mathrm{kg} \mathrm{BW} / \mathrm{d}$ estradiol (E2) and ovariectomized animals treated with 6-(1,1dimethylallyl)naringenin (6-DMAN) and 8-prenylnaringenin (8-PN) at a concentration of $15 \mathrm{mg} / \mathrm{kg} / \mathrm{d}$ BW. Significancies are indicated as described in Fig.3.

Fig.6: Realtime RT-PCR analysis of uterine gene expression:

Expression of the Cyclooxygenase 2 (COX2) and clusterin mRNA was analyzed by quantitative real-time RT-PCR analysis. Data of uterine gene expression of untreated ovariectomized control (Co), ovariectomized animals treated with $10 \mu \mathrm{g} / \mathrm{kg} \mathrm{BW} / \mathrm{d}$ estradiol (E2) and ovariectomized animals treated with 6-(1,1-dimethylallyl)naringenin (6-DMAN) and 8-prenylnaringenin (8-PN) at a concentration of $15 \mathrm{mg} / \mathrm{kg} / \mathrm{d} \mathrm{BW}$. Significancies are indicated as described in Fig.3.

Fig.7: Realtime RT-PCR analysis of uterine gene expression:

Expression of the vascular endothelial growth factor (VEGF) and it's receptor 2 (VEGFR2) mRNA was analyzed by quantitative real-time RT-PCR analysis. Data of uterine gene expression of untreated ovariectomized control (Co), ovariectomized animals treated with $10 \mu \mathrm{g} / \mathrm{kg} \mathrm{BW} / \mathrm{d}$ estradiol (E2) and ovariectomized animals treated with 6-(1,1-dimethylallyl)naringenin (6-DMAN) and 8-prenylnaringenin (8-PN) at a concentration of $15 \mathrm{mg} / \mathrm{kg} / \mathrm{d}$ BW. Significancies are indicated as described in Fig.3.

Fig.8: Realtime RT-PCR analysis of uterine gene expression and uterine PCNA protein level:

Expression of the proliferation markers $\mathrm{KI} 67$ and PCNA mRNA was analyzed by quantitative real-time RT-PCR analysis $(A+B)$ and densitometric analysis of PCNA protein levels after Western Blot analysis (C). Data of uterine gene expression respectively PCNA protein level of untreated ovariectomized control (Co), 
ovariectomized animals treated with $10 \mu \mathrm{g} / \mathrm{kg}$ BW/d estradiol (E2) and ovariectomized animals treated with 6-(1,1-dimethylallyl)naringenin (6-DMAN) and 8prenylnaringenin (8-PN) at a concentration of $15 \mathrm{mg} / \mathrm{kg} / \mathrm{d}$ BW. Significancies are indicated as described in Fig. 3. 


\section{References}

Bennetts HW, Underwood EJ, Shier FL. 1946. A specific breeding problem of sheep on subterranean clover pastures in Western Australia. Aust. Vet. J. 22:2-12.

Brown NM, Setchell KD. 2001. Animal models impacted by phytoestrogens in commercial chow: implications for pathways influenced by hormones. Lab Invest 81:735-747.

Byers M, Kuiper GG, Gustafsson JA, Park-Sarge OK. 1997. Estrogen receptor-beta mRNA expression in rat ovary: down-regulation by gonadotropins. Mol Endocrinol 11:172-182.

Coleman KM, Smith CL. 2001. Intracellular signaling pathways: nongenomic actions of estrogens and ligand-independent activation of estrogen receptors. Front Biosci 6:D1379-1391.

Cos P, De Bruyne T, Apers S, Berghe DV, Pieters L, Vlietinck AJ. 2003. Phytoestrogens: recent developments. Planta Med 69:589-599.

Diel P, Thomae RB, Caldarelli A, Zierau O, Kolba S, Schmidt S, Schwab P, Metz P, Vollmer G. 2004. Regulation of gene expression by 8-prenylnaringenin in uterus and liver of Wistar rats. Planta Med 70:39-44.

Gester S, Metz P, Zierau O, Vollmer G. 2001. An Efficient Synthesis of the Potent Phytoestrogens 8-Prenylnaringenin and 6-(1,1-Dimethylallyl)naringenin by Europium(III)-Catalyzed Claisen Rearrangement. Tetrahedron 57:1015-1018.

Ito K. 2007. Hormone replacement therapy and cancers: the biological roles of estrogen and progestin in tumorigenesis are different between the endometrium and breast. Tohoku J Exp Med 212:1-12.

Jakacka M, Ito M, Martinson F, Ishikawa T, Lee EJ, Jameson JL. 2002. An estrogen receptor (ER)alpha deoxyribonucleic acid-binding domain knock-in mutation provides evidence for nonclassical ER pathway signaling in vivo. Mol Endocrinol 16:2188-2201.

Kitaoka M, Kadokawa H, Sugano M, Ichikawa K, Taki M, Takaishi S, lijima Y, Tsutsumi S, Boriboon M, Akiyama T. 1998. Prenylflavonoids: a new class of non-steroidal phytoestrogen (Part 1). Isolation of 8-isopentenylnaringenin and an initial study on its structure-activity relationship. Planta Med 64:511-515.

Krebs EE, Ensrud KE, MacDonald R, Wilt TJ. 2004. Phytoestrogens for treatment of menopausal symptoms: a systematic review. Obstet Gynecol 104:824-836.

Kretzschmar G, Vollmer G, Schwab P, Tischer S, Metz P, Zierau O. 2007. Effects of the chemically synthesized flavanone 7-(O-prenyl)naringenin-4'-acetate on the estrogen signaling pathway in vivo and in vitro. J Steroid Biochem Mol Biol 107:114-119.

Kuiper GG, Enmark E, Pelto-Huikko M, Nilsson S, Gustafsson JA. 1996. Cloning of a novel receptor expressed in rat prostate and ovary. Proc Natl Acad Sci U S A 93:5925-5930.

Kuiper GG, Lemmen JG, Carlsson B, Corton JC, Safe SH, van der Saag PT, van der Burg B, Gustafsson JA. 1998. Interaction of estrogenic chemicals and phytoestrogens with estrogen receptor beta. Endocrinology 139:4252-4263.

Kushner PJ, Agard DA, Greene GL, Scanlan TS, Shiau AK, Uht RM, Webb P. 2000. Estrogen receptor pathways to AP-1. J Steroid Biochem Mol Biol 74:311-317.

Matsumura A, Ghosh A, Pope GS, Darbre PD. 2005. Comparative study of oestrogenic properties of eight phytoestrogens in MCF7 human breast cancer cells. J Steroid Biochem Mol Biol 94:431-443. 
Milligan S, Kalita J, Pocock V, Heyerick A, De Cooman L, Rong H, De Keukeleire D. 2002. Oestrogenic activity of the hop phyto-oestrogen, 8-prenylnaringenin. Reproduction 123:235-242.

Milligan SR, Kalita JC, Heyerick A, Rong H, De Cooman L, De Keukeleire D. 1999. Identification of a potent phytoestrogen in hops (Humulus lupulus L.) and beer. $\mathrm{J}$ Clin Endocrinol Metab 84:2249-2252.

Moller F, Zierau O, Jandausch A, Rettenberger R, Kaszkin-Bettag M, Vollmer G. 2007. Subtype-specific activation of estrogen receptors by a special extract of Rheum rhaponticum (ERr 731), its aglycones and structurally related compounds in U2OS human osteosarcoma cells. Phytomedicine 14:716-726.

Nagata C, Takatsuka N, Kawakami N, Shimizu H. 2001. Soy product intake and hot flashes in Japanese women: results from a community-based prospective study. Am J Epidemiol 153:790-793.

Ososki AL, Kennelly EJ. 2003. Phytoestrogens: a review of the present state of research. Phytother Res 17:845-869.

Rad M, Humpel M, Schaefer O, Schoemaker RC, Schleuning WD, Cohen AF, Burggraaf J. 2006. Pharmacokinetics and systemic endocrine effects of the phyto-oestrogen 8-prenylnaringenin after single oral doses to postmenopausal women. Br J Clin Pharmacol 62:288-296.

Ray A, Prefontaine KE, Ray P. 1994. Down-modulation of interleukin-6 gene expression by 17 beta-estradiol in the absence of high affinity DNA binding by the estrogen receptor. J Biol Chem 269:12940-12946.

Roelens F, Heldring N, Dhooge W, Bengtsson M, Comhaire F, Gustafsson JA, Treuter E, De Keukeleire D. 2006. Subtle side-chain modifications of the hop phytoestrogen 8-prenylnaringenin result in distinct agonist/antagonist activity profiles for estrogen receptors alpha and beta. J Med Chem 49:7357-7365.

Safe S. 2001. Transcriptional activation of genes by 17 beta-estradiol through estrogen receptor-Sp1 interactions. Vitam Horm 62:231-252.

Saunders PT, Maguire SM, Gaughan J, Millar MR. 1997. Expression of oestrogen receptor beta (ER beta) in multiple rat tissues visualised by immunohistochemistry. J Endocrinol 154:R13-16.

Schaefer O, Humpel M, Fritzemeier KH, Bohlmann R, Schleuning WD. 2003. 8Prenyl naringenin is a potent ERalpha selective phytoestrogen present in hops and beer. J Steroid Biochem Mol Biol 84:359-360.

Seo EK, Silva GL, Chai HB, Chagwedera TE, Farnsworth NR, Cordell GA, Pezzuto JM, Kinghorn AD. 1997. Cytotoxic prenylated flavanones from Monotes engleri. Phytochemistry 45:509-515.

Singleton DW, Khan SA. 2003. Xenoestrogen exposure and mechanisms of endocrine disruption. Front Biosci 8:s110-118.

Tokalov SV, Henker Y, Schwab P, Metz P, Gutzeit HO. 2004. Toxicity and cell cycle effects of synthetic 8-prenylnaringenin and derivatives in human cells. Pharmacology 71:46-56.

Vollmer G, Zierau O. 2004. [What are phytoestrogens and phyto-SERMS]. Pharm Unserer Zeit 33:378-383.

Whitten PL, Patisaul HB. 2001. Cross-species and interassay comparisons of phytoestrogen action. Environ Health Perspect 109 Suppl 1:5-20.

Winer J, Jung CK, Shackel I, Williams PM. 1999. Development and validation of realtime quantitative reverse transcriptase-polymerase chain reaction for monitoring gene expression in cardiac myocytes in vitro. Anal Biochem 270:41-49. 
Zierau O, Geis RB, Tischer S, Schwab P, Metz P, Vollmer G. 2004. Uterine effects of the phytoestrogen 6-(1,1-dimethylallyl)naringenin in rats. Planta Med 70:590593.

Zierau O, Gester S, Schwab P, Metz P, Kolba S, Wulf M, Vollmer G. 2002.

Estrogenic activity of the phytoestrogens naringenin, 6-(1,1-

dimethylallyl)naringenin and 8-prenylnaringenin. Planta Med 68:449-451.

Zierau O, Morrissey C, Watson RW, Schwab P, Kolba S, Metz P, Vollmer G. 2003. Antiandrogenic activity of the phytoestrogens naringenin, 6-(1,1dimethylallyl)naringenin and 8-prenylnaringenin. Planta Med 69:856-858. 


\section{Fig. 1}<smiles>CC(C)=CCc1c(O)cc(O)c2c1O[C@H](c1ccc(O)cc1)CC2=O</smiles>

a. ( \pm ) 8-prenylnaringenin

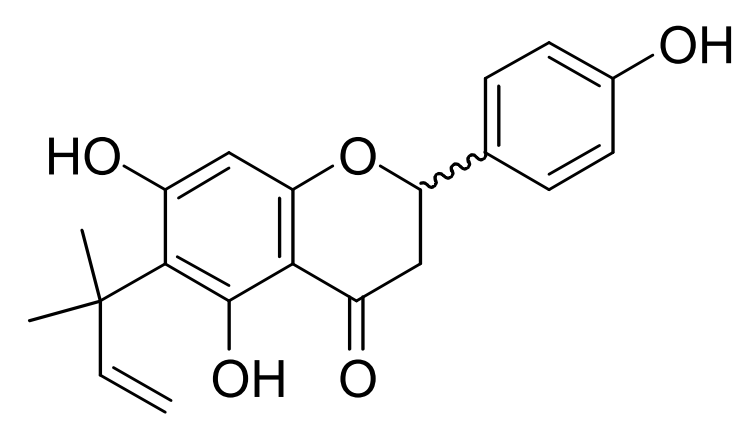

b. ( \pm ) 6-(1,1-dimethylallyl)naringenin 


\section{Fig. 2}
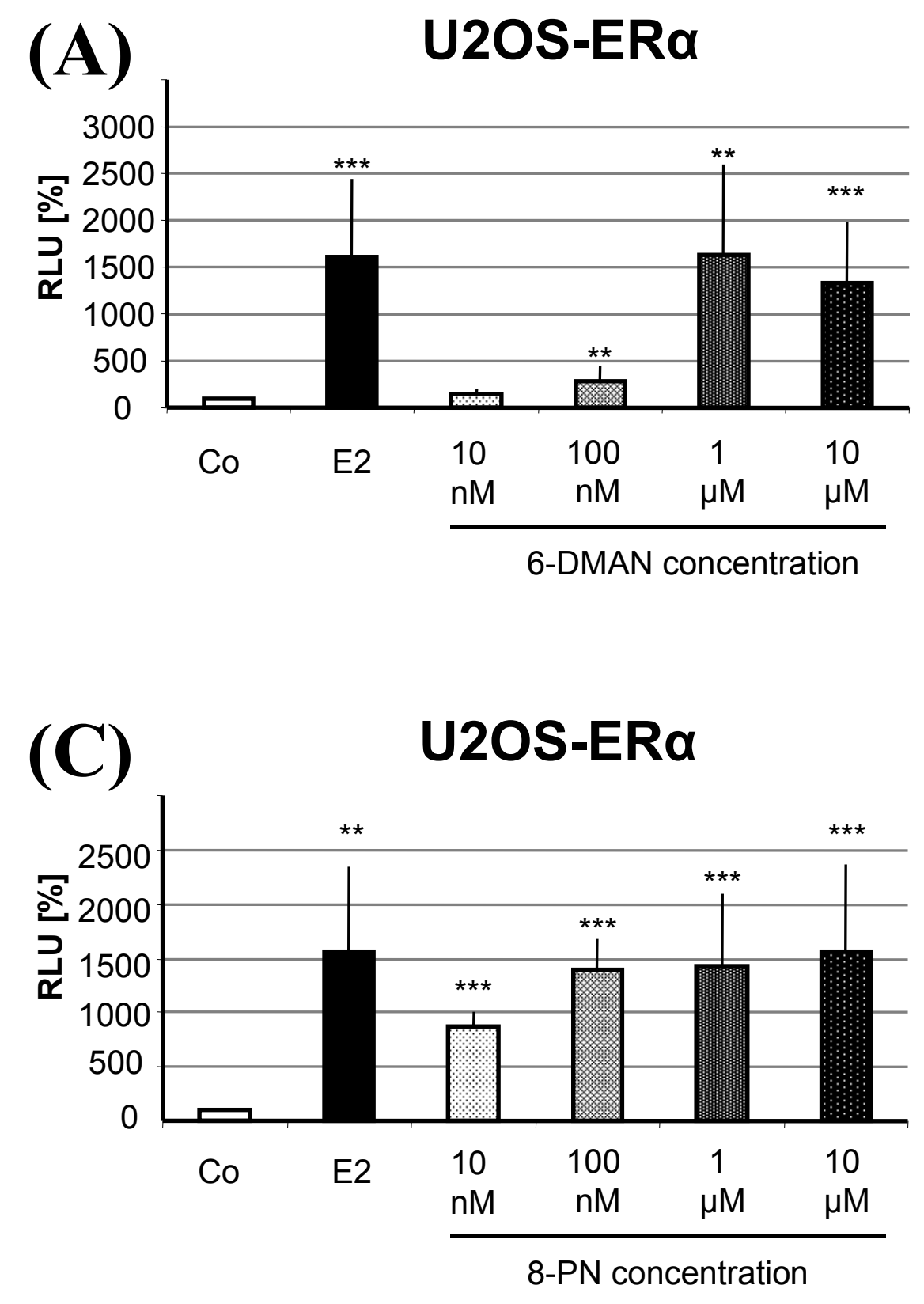
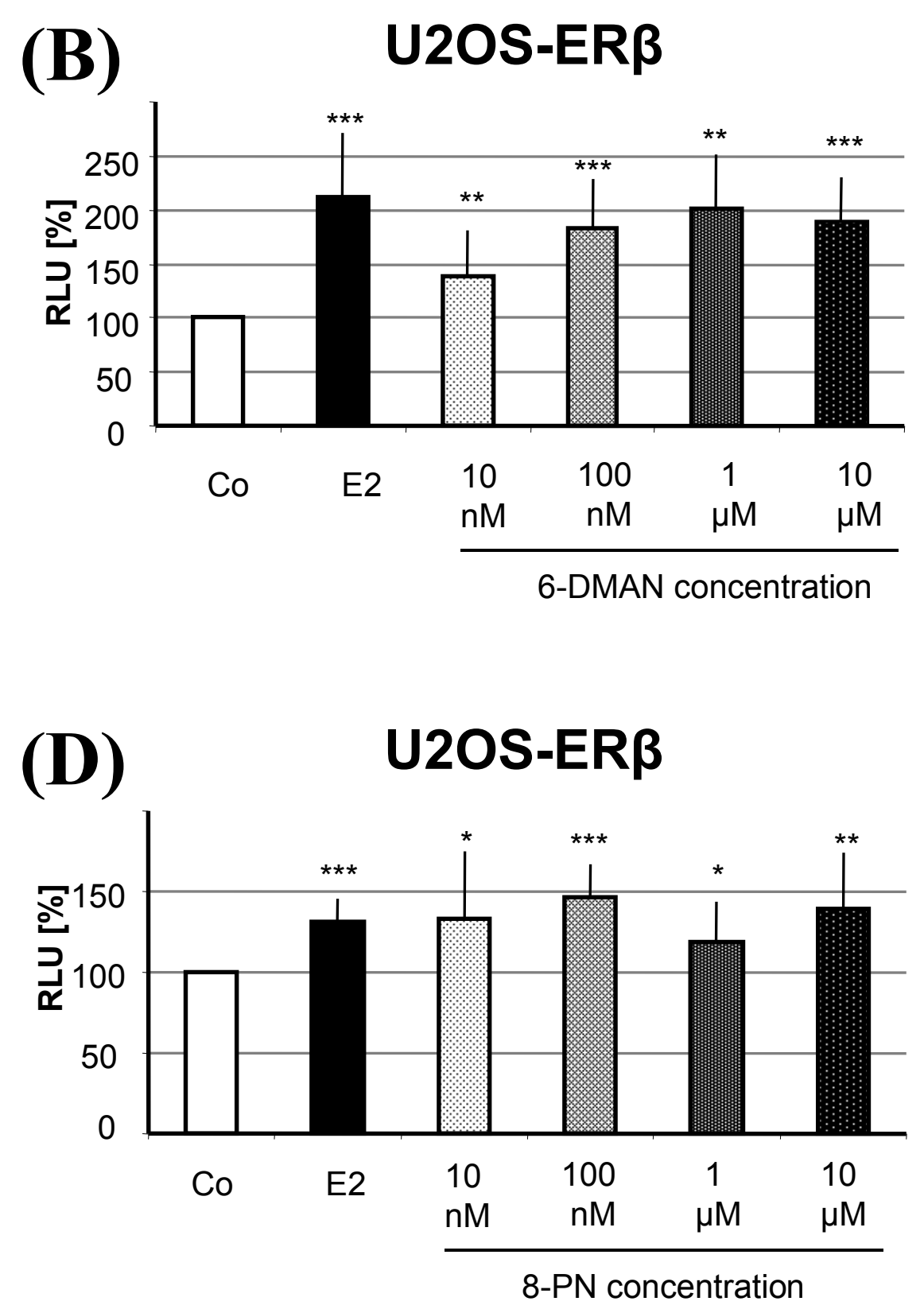
Fig. 3

Uterine wet weight in $\mathbf{g}$

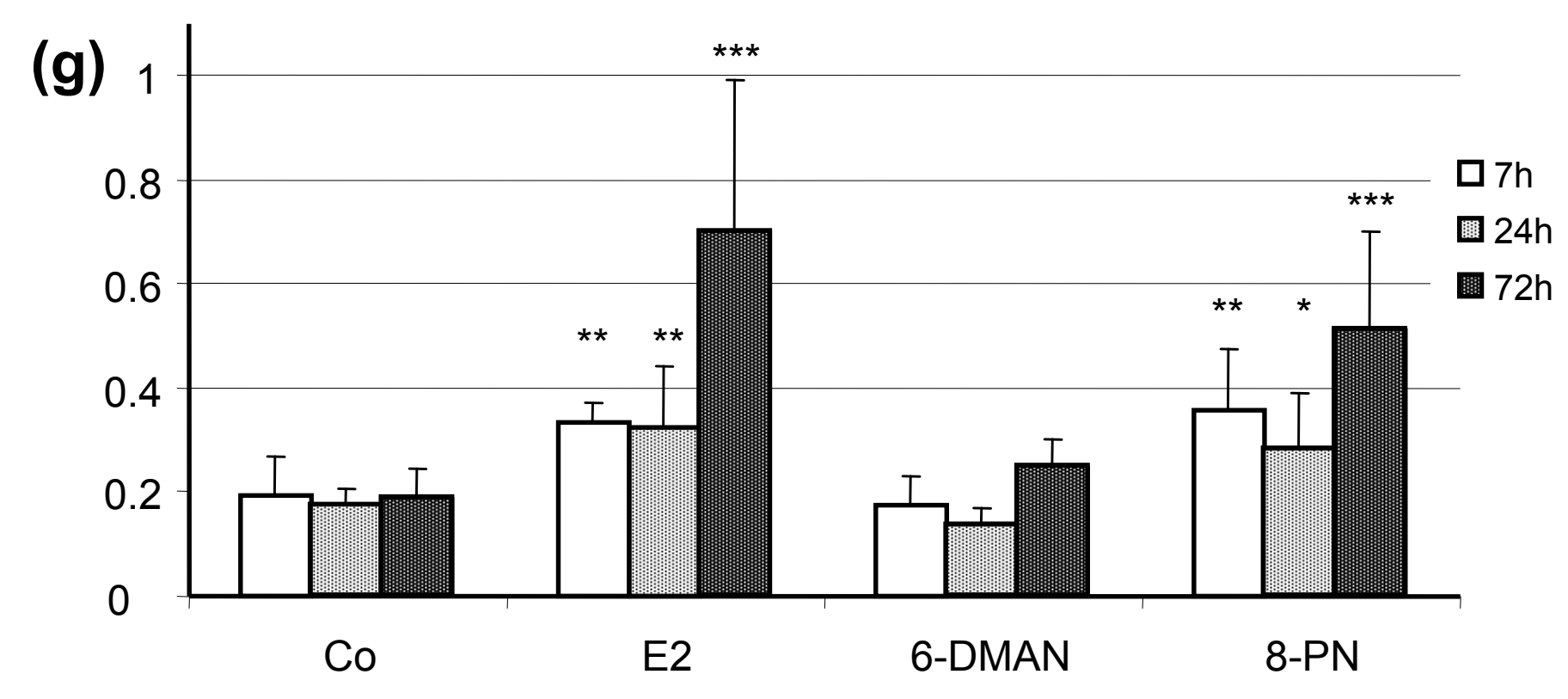


Fig. 4

ER alpha

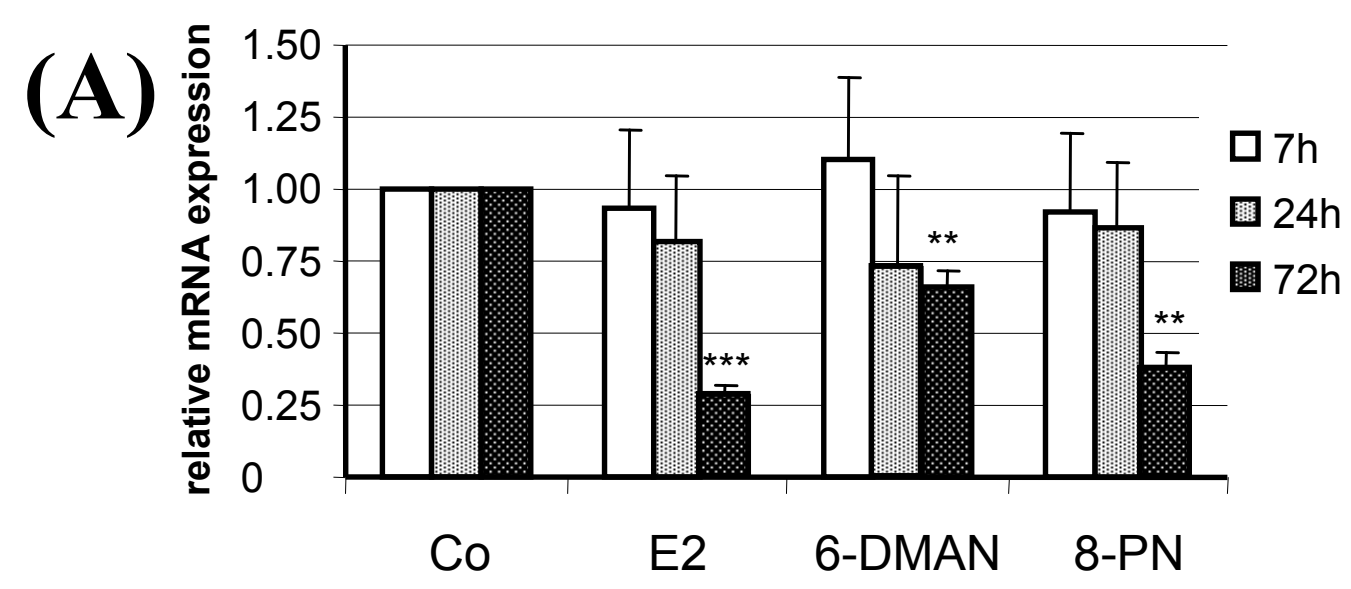

ER beta

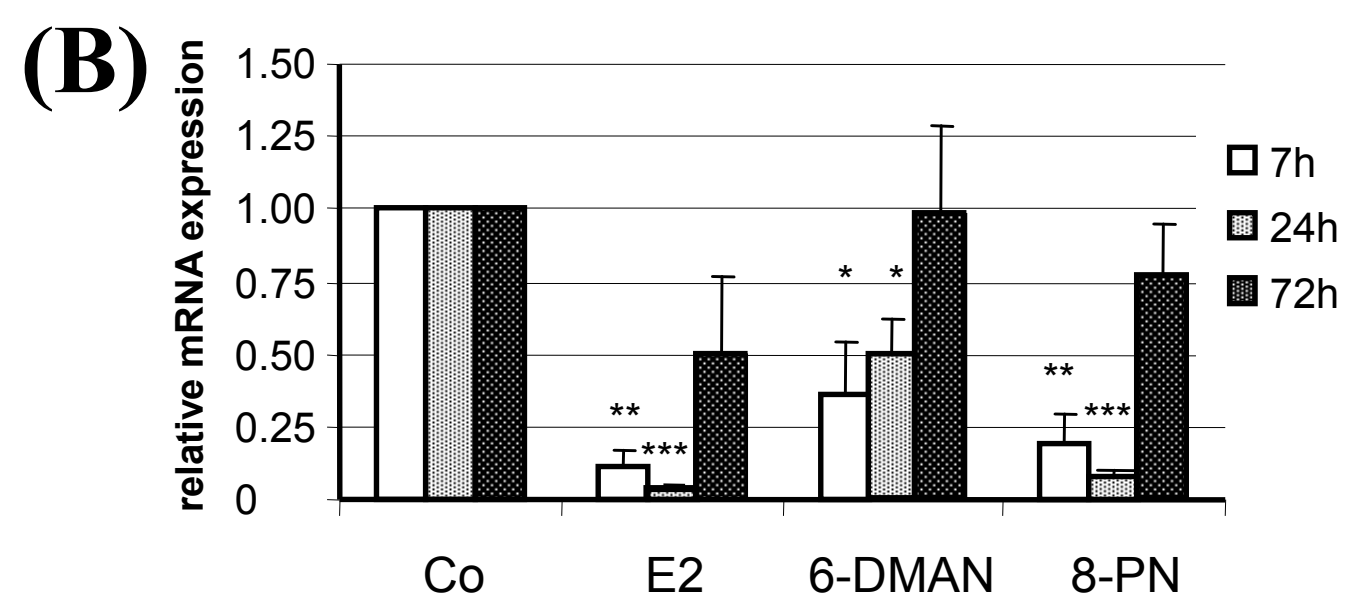


Fig. 5

\section{Complement C3}

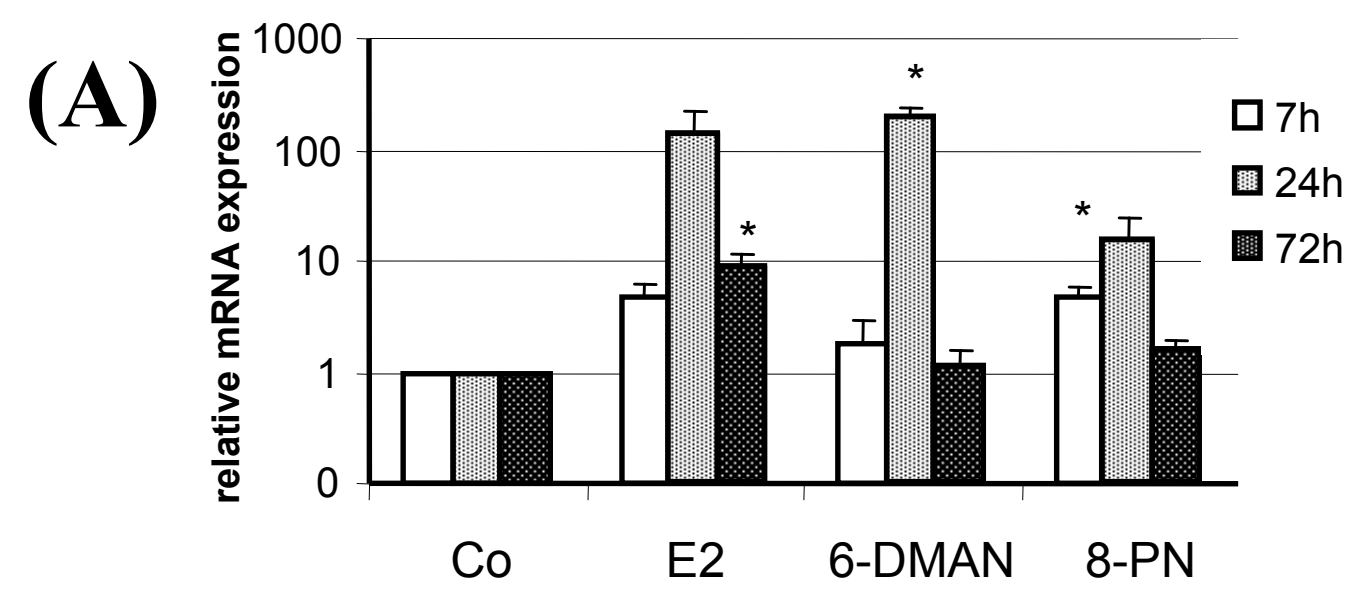

\section{PR}

(B)

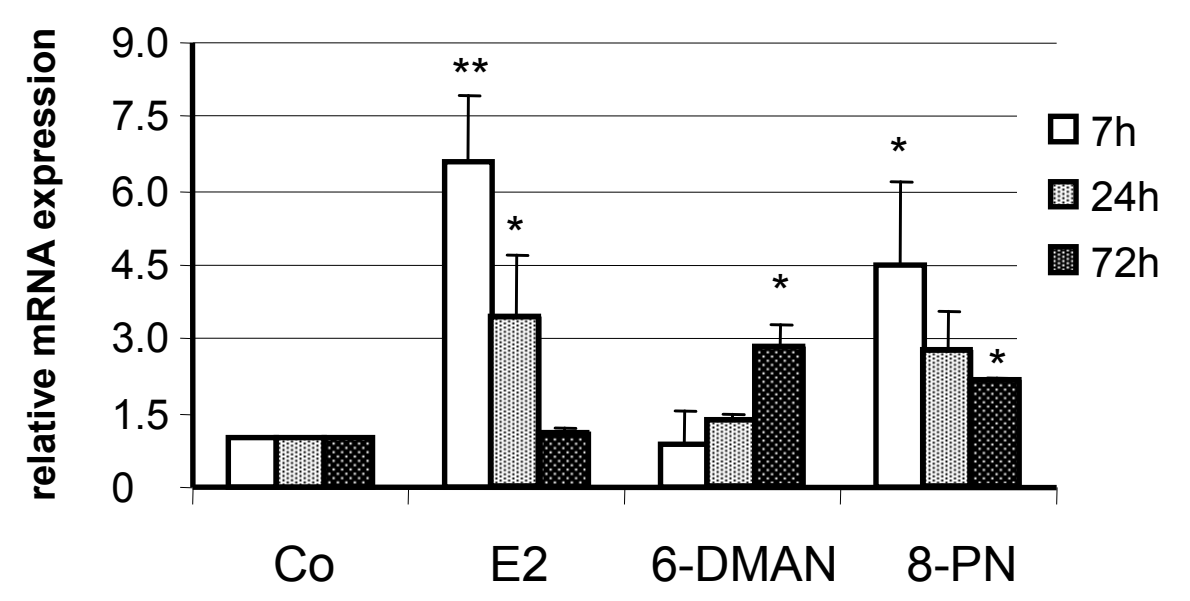


Fig. 6

\section{$\operatorname{cox} 2$}

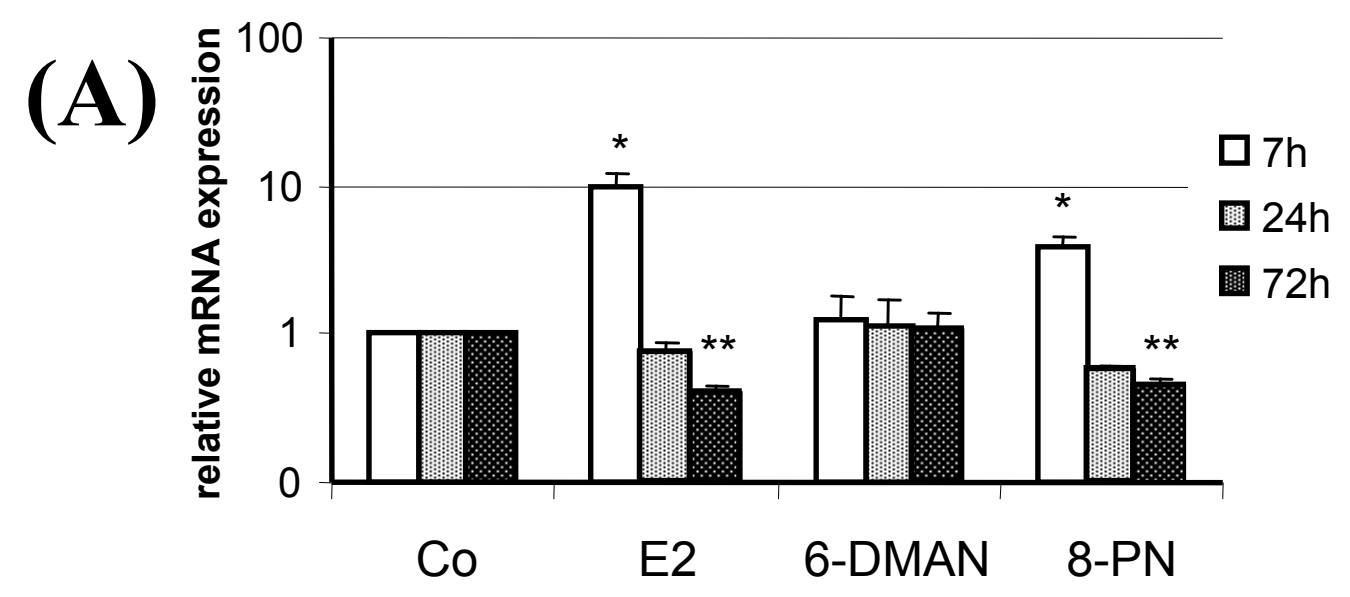

Clusterin

(B)

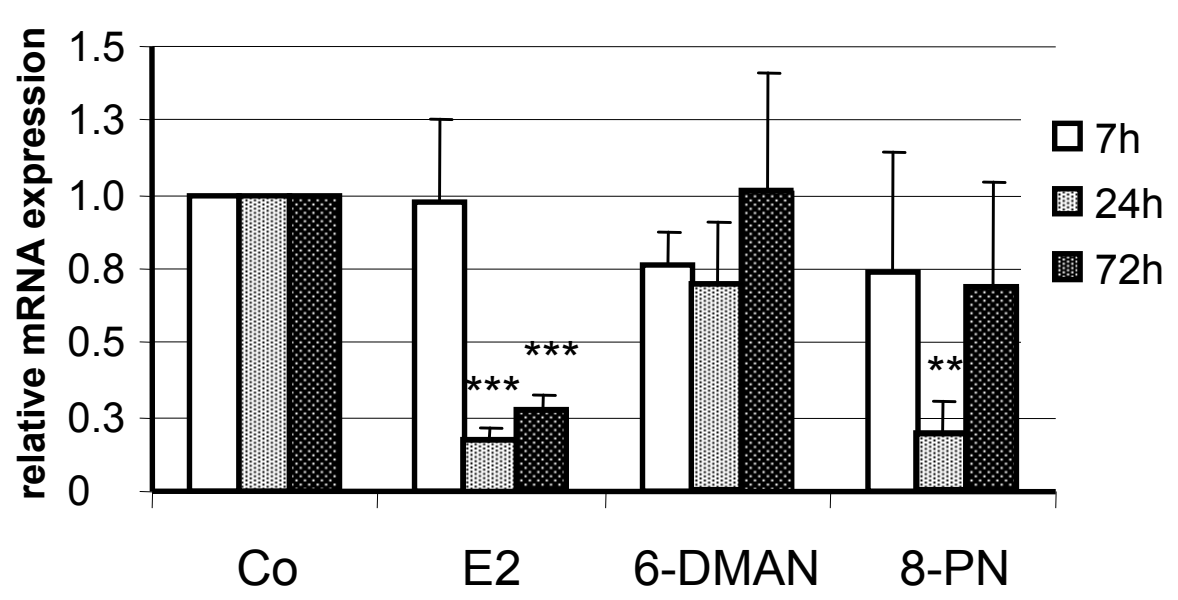


Fig. 7

\section{VEGF}
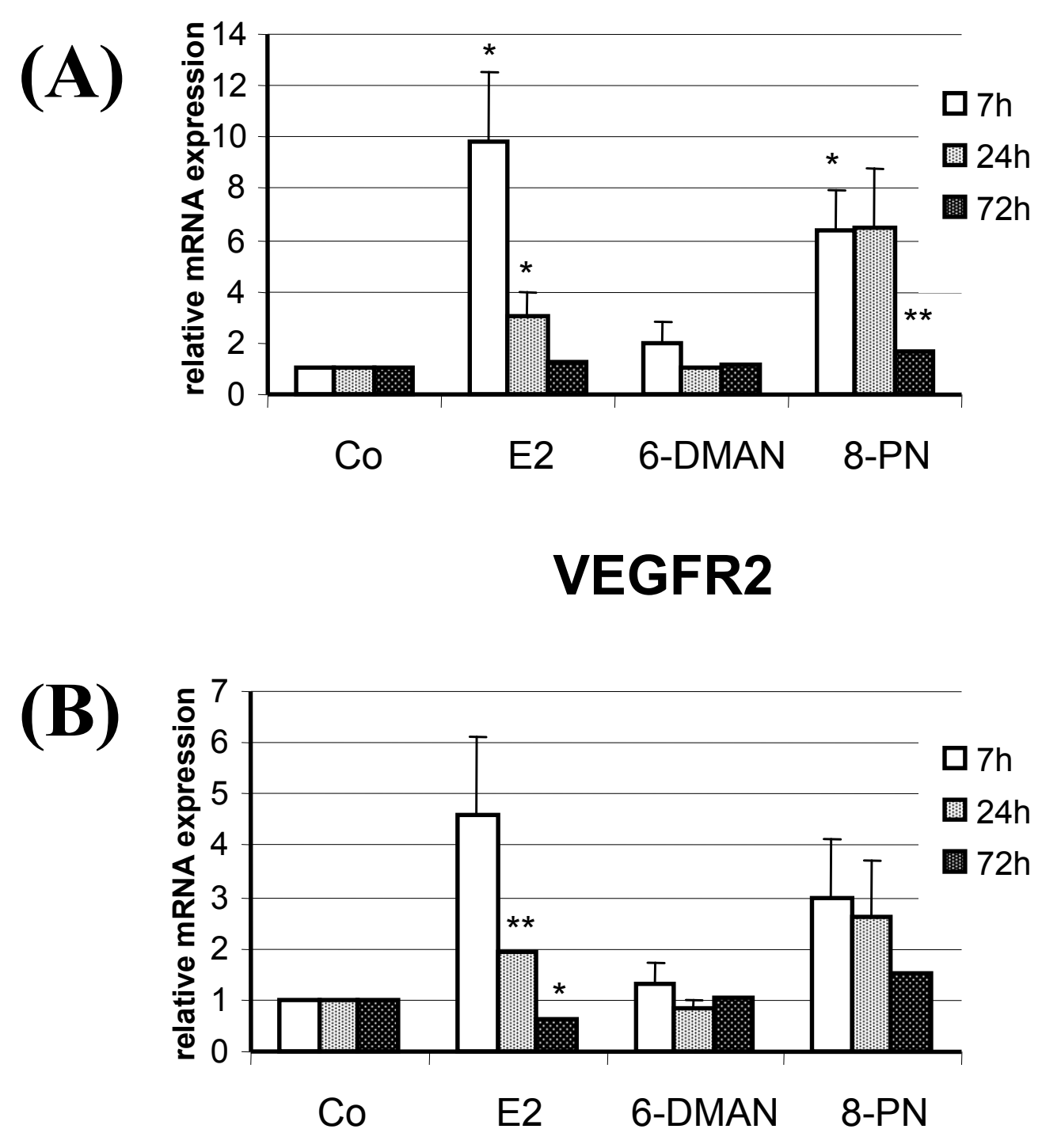
Fig. 8

(A)

\section{KI67}

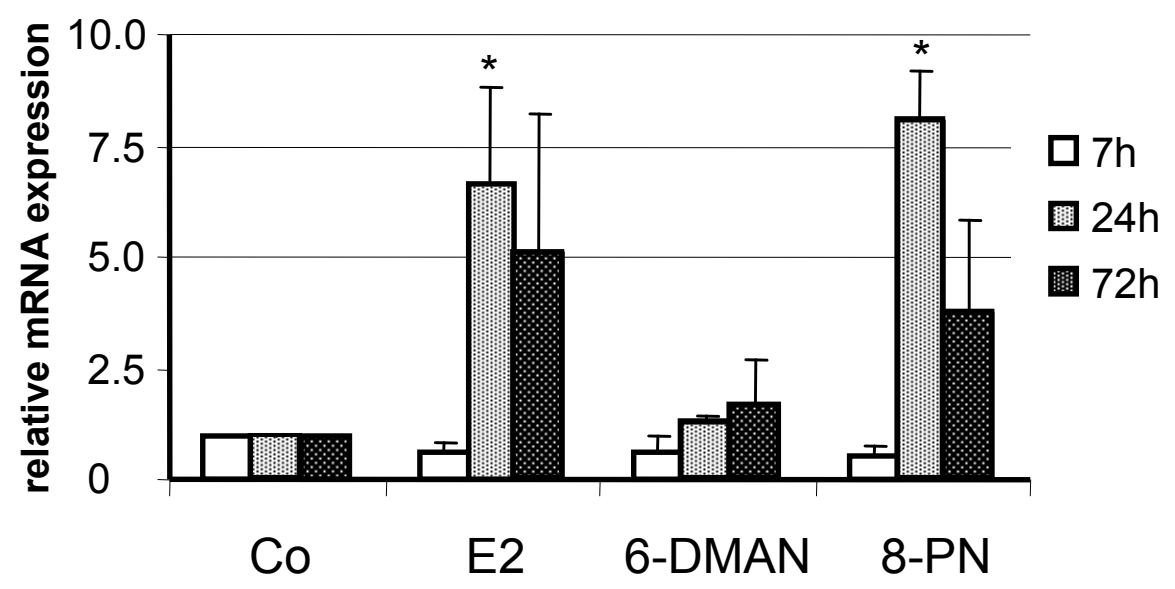

(B)

PCNA

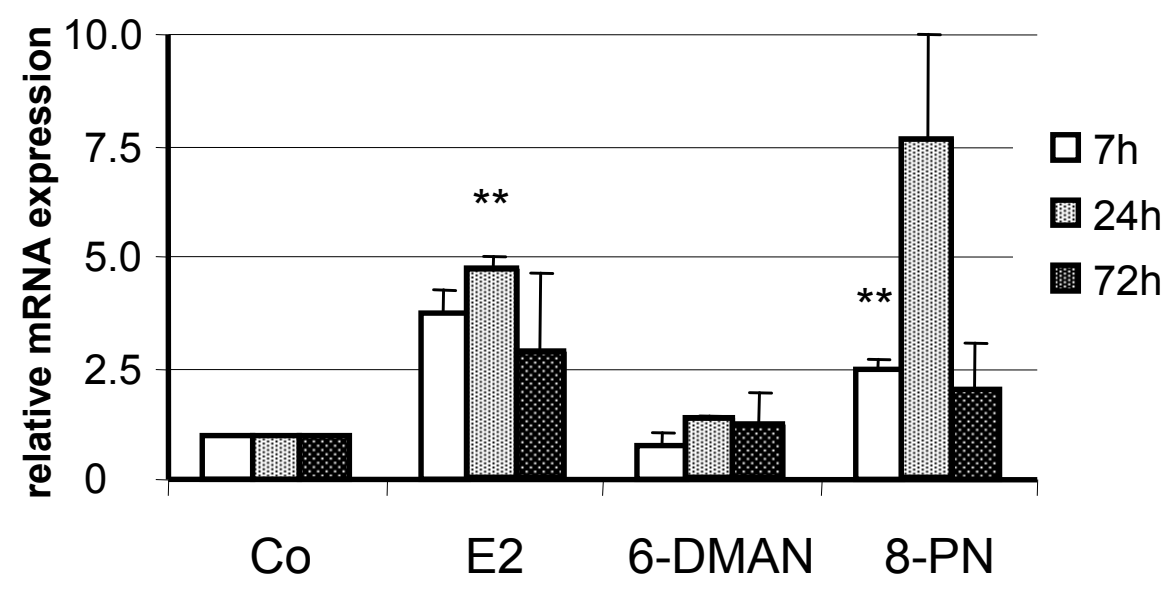

(C)

PCNA Protein

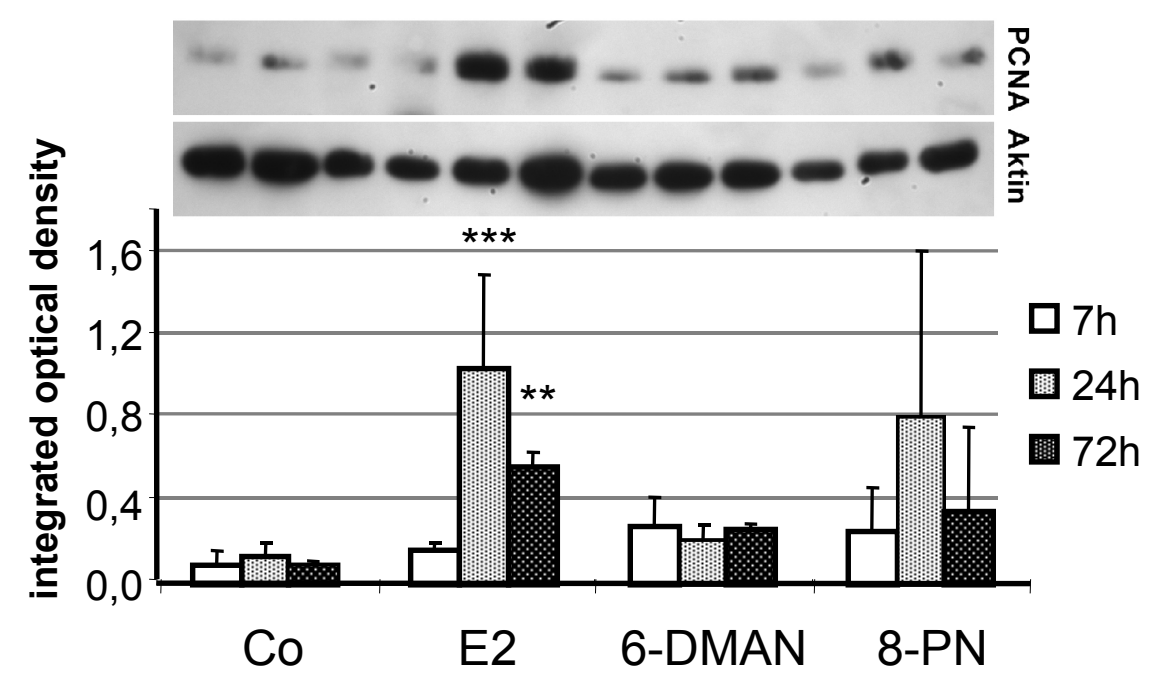




\section{Table 1}

\begin{tabular}{|l|l|c|}
\hline \multicolumn{1}{|c|}{ genes } & \multicolumn{1}{|c|}{ primer } & $\begin{array}{c}\text { amplicon } \\
\text { size }\end{array}$ \\
\hline Cytochrome C Oxidase I (1A): & $\begin{array}{l}\text { forward 5' TGA GCA GGA ATA GTA GGG ACA GC 3' } \\
\text { reverse 5' GAG TAG AAA TGA TGG AGG AAG CA 3' }\end{array}$ & 261 bp \\
\hline Estrogen receptor (ER) $\boldsymbol{\alpha}$ & $\begin{array}{l}\text { forward 5' GGA AGC ACA AGC GTC AGA GAG AT 3' } \\
\text { reverse 5' AGA CCA GAC CAA TCA TCA GGA T 3' }\end{array}$ & 383 bp \\
\hline Estrogen receptor (ER) $\boldsymbol{\beta}$ & $\begin{array}{l}\text { forward 5' CTA CAG AGA TGG TCA AAA GTG GAA 3' } \\
\text { reverse 5' GGG CAA GGA GAC AGA AAG TAA GT 3' }\end{array}$ & 216 bp \\
\hline Complement C3 (C3): & $\begin{array}{l}\text { forward 5' ACA GCC TTC CCG GGA GCA TCA ACA3' } \\
\text { reverse 5' AGC GCA CCA CAG GAG GCA CAG AGT C3' }\end{array}$ & 276 bp \\
\hline Progesterone receptor (PR): & $\begin{array}{l}\text { forward 5' CCC AGA CGA AAA GAC ACA AAA T 3' } \\
\text { reverse 5' CCA AAG AGA CAC CAA GAA GTG AT 3' }\end{array}$ & 222 bp \\
\hline Clusterin (CLU) & $\begin{array}{l}\text { forward 5'-CCC TCC AGT CCA AGA TGC TCA ACA C-3' } \\
\text { reverse 5'-CCA TGC GGC TTT TCC TGC GGT ATT C-3 }\end{array}$ & 303 bp \\
\hline $\begin{array}{l}\text { Proliferation-related Ki-67 } \\
\text { antigen (KI67): }\end{array}$ & $\begin{array}{l}\text { forward 5'-AAC CAG GAC TTT GTG CTC TGT AA-3' } \\
\text { reverse 5'-CTC TTT TGG CTT CCA TTT CTT C-3' }\end{array}$ & 209 bp \\
\hline $\begin{array}{l}\text { Proliferating cell nuclear } \\
\text { antigen (PCNA): }\end{array}$ & $\begin{array}{l}\text { forward 5'-GAG CAA CTT GGA ATC CCA GAA CAG G-3' } \\
\text { reverse 5'-CCA AGC TCC CCA CTC GCA GAA AAC T-3' }\end{array}$ & 158 bp \\
\hline Cyclooxygenase 2 (COX2): & $\begin{array}{l}\text { forward 5'-AAC TGT ATC CCG CCC TGC TGG TG-3' } \\
\text { reverse 5'-AGA CAG CCA CCA TCA ACG CAA GT-3' }\end{array}$ & 284 bp \\
\hline $\begin{array}{l}\text { Vascular endothelial growth } \\
\text { factor receptor 2 (VEGFR2): }\end{array}$ & $\begin{array}{l}\text { forward 5'-GAA AAA GCC GGC CAG TGA GTG TAA-3' } \\
\text { reverse 5' AGC GCA GTG TGG TCC CAG CAG AGT CAA-3' }\end{array}$ & 345 bp \\
\hline
\end{tabular}




\section{Table 2}

\begin{tabular}{|c|c|c|c|c|c|c|c|c|c|}
\hline & \multicolumn{3}{|c|}{ E2 } & \multicolumn{3}{|c|}{ 6-DMAN } & \multicolumn{3}{|c|}{ 8-PN } \\
\hline & $7 \mathrm{~h}$ & $24 h$ & $72 \mathrm{~h}$ & $7 \mathrm{~h}$ & $24 \mathrm{~h}$ & $72 \mathrm{~h}$ & $7 \mathrm{~h}$ & $24 \mathrm{~h}$ & $72 \mathrm{~h}$ \\
\hline$E R \alpha$ & & & $\downarrow \downarrow$ & & & $\downarrow$ & & & $\downarrow \downarrow$ \\
\hline ER $\beta$ & $\downarrow \downarrow$ & $\downarrow \downarrow$ & $(\downarrow)$ & $\downarrow$ & $\downarrow$ & & $\downarrow \downarrow$ & $\downarrow \downarrow$ & \\
\hline C3 & $\uparrow$ & $\uparrow \uparrow$ & $\uparrow \uparrow$ & $(\uparrow)$ & $\uparrow \uparrow$ & & $\uparrow$ & $\uparrow \uparrow$ & \\
\hline PR & $\uparrow \uparrow$ & $\uparrow$ & & & & $\uparrow$ & $\uparrow \uparrow$ & $\uparrow$ & $\uparrow$ \\
\hline Cox 2 & $\uparrow \uparrow$ & & $(\downarrow)$ & & & & $\overline{\uparrow \uparrow}$ & & $(\downarrow)$ \\
\hline Clusterin & & $\downarrow \downarrow$ & $\downarrow \downarrow$ & & & & & $\downarrow \downarrow$ & \\
\hline VEGF & $\uparrow \uparrow$ & $\uparrow$ & & & & & $\uparrow \uparrow$ & $\uparrow$ & $(\uparrow)$ \\
\hline VEGF-R2 & $\bar{\uparrow}$ & $\uparrow \uparrow$ & $(\downarrow)$ & & & & $\bar{\uparrow}$ & $(\uparrow)$ & \\
\hline Ki67 & & $\uparrow \uparrow$ & $\bar{\uparrow}$ & & & & & $\overline{\uparrow \uparrow}$ & $\uparrow$ \\
\hline PCNA & $\uparrow$ & $\uparrow \uparrow$ & $(\uparrow)$ & & & & $\uparrow$ & $\uparrow \uparrow$ & \\
\hline
\end{tabular}

